\title{
Effects of a combination of feed additives on methane production, diet digestibility, and animal performance in lactating dairy cows
}

\author{
S. M. van Zijderveld, ${ }^{\star 1}$ B. Fonken, $†$ J. Dijkstra, $†$ W. J. J. Gerrits, $†$ H. B. Perdok, ${ }^{*}$ W. Fokkink, ${ }^{* 2}$ \\ and J. R. Newbold* \\ *Provimi Holding B.V., Research Centre De Viersprong, Veilingweg 23, NL-5334LD, Velddriel, the Netherlands \\ †Animal Nutrition Group, Wageningen University, P.O. Box 338, 6700 AH Wageningen, the Netherlands
}

\begin{abstract}
Two experiments were conducted to assess the effects of a mixture of dietary additives on enteric methane production, rumen fermentation, diet digestibility, energy balance, and animal performance in lactating dairy cows. Identical diets were fed in both experiments. The mixture of feed additives investigated contained lauric acid, myristic acid, linseed oil, and calcium fumarate. These additives were included at $0.4,1.2,1.5$, and $0.7 \%$ of dietary dry matter, respectively (treatment ADD). Experimental fat sources were exchanged for a rumen inert source of fat in the control diet (treatment CON) to maintain isolipidic rations. Cows (experiment $1, \mathrm{n}=$ 20 ; experiment $2, \mathrm{n}=12$ ) were fed restricted amounts of feed to avoid confounding effects of dry matter intake on methane production. In experiment 1 , methane production and energy balance were studied using open-circuit indirect calorimetry. In experiment 2, 10 rumen-fistulated animals were used to measure rumen fermentation characteristics. In both experiments animal performance was monitored. The inclusion of dietary additives decreased methane emissions $(\mathrm{g} / \mathrm{d})$ by $10 \%$. Milk yield and milk fat content tended to be lower for ADD in experiment 1 . In experiment 2 , milk production was not affected by ADD, but milk fat content was lower. Fat- and protein-corrected milk was lower for ADD in both experiments. Milk urea nitrogen content was lowered by ADD in experiment 1 and tended to be lower in experiment 2. Apparent total tract digestibility of fat, but not that of starch or neutral detergent fiber, was higher for ADD. Energy retention did not differ between treatments. The decrease in methane production $(\mathrm{g} / \mathrm{d})$ was not evident when methane emission was expressed per kilogram of milk produced. Feeding ADD resulted in increases of $\mathrm{C} 12: 0$ and $\mathrm{C} 14: 0$ and the inter-
\end{abstract}

\footnotetext{
Received July 20, 2010.

Accepted December 7, 2010.

${ }^{1}$ Corresponding author: svanzijderveld@nl.provimi.com

${ }^{2}$ Current address: Provimi North America, Nutrition and Research Center, 250 W. Clay Street, Lewisburg, OH 45338.
}

mediates of linseed oil biohydrogenation in milk in both experiments. In experiment 2, ADD-fed cows tended to have a decreased number of protozoa in rumen fluid when compared with that in control cows. Total volatile fatty acid concentrations were lower for ADD, whereas molar proportions of propionate increased at the expense of acetate and butyrate.

Key words: methane, dairy cow, feed additive

\section{INTRODUCTION}

Atmospheric methane concentrations have increased from a level of $715 \mathrm{ppb}$ in the pre-industrial era to a level of 1,774 ppb in 2005 (Forster et al., 2007), probably due to an increase in the global human population and its concomitant production of greenhouse gases. Agricultural practice is responsible for a considerable part of anthropogenic methane production and enteric fermentation by ruminants is considered to be the single largest global source of anthropogenic methane emissions (86 million tonnes per annum; Steinfeld et al., 2006). Dietary composition has a large influence on the amount of methane produced by ruminants and dietary intervention is an interesting option to decrease methane emissions (Ellis et al., 2008). Methane losses can vary as much as 2 to $12 \%$ of the ingested gross energy by the animal (Johnson and Johnson, 1995).

Dietary fat addition has been shown to decrease methane production by ruminants in many studies (Jordan et al., 2006b; Machmüller, 2006; Martin et al., 2008). However, a recent meta-analysis (Eugene et al., 2008), showed that the decrease in methane emission caused by feeding fat to dairy cows was associated with a decrease in DMI. In addition, dietary fat addition will also decrease the proportion of fermentable organic matter (FOM) in the diet, which in itself would decrease methane emissions. Therefore, the potential of dietary strategies to decrease methane emissions should be evaluated at similar DMI and similar dietary fat content.

In the current experiments, we evaluated the methane mitigating properties of a mixture of feed components 
(mainly lipids), while maintaining a similar dietary concentration of both FOM and lipid and a similar DMI. We hypothesized that part of the methane mitigating effects, reported previously for these additives were indirectly caused by differences in DMI or FOM concentration.

\section{MATERIALS AND METHODS}

\section{Experimental Design}

Experiment 1 was a randomized block design with 2 treatments involving 20 lactating Holstein-Friesian dairy cows with fat- and protein-corrected milk (FPCM) production of $32.8 \pm 4.9 \mathrm{~kg} / \mathrm{d}$ and $176 \pm 76$ DIM at the beginning of the experiment. Cows were paired (10 pairs of 2 cows) based on FPCM production, parity, and DIM before the experiment. Within each pair, cows were randomly assigned to either the control treatment $(\mathbf{C O N})$ or the treatment with the additives (ADD). Treatment periods lasted $21 \mathrm{~d}$. The experiment was carried out in 5 identical replicates. In each replicate, 4 cows (2 on each treatment) were housed in tie-stalls for a 14-d period to adapt to restriction in movement and the experimental diets. After the adaptation period, 2 cows, belonging to the same treatment group, were housed in respiration chambers for $7 \mathrm{~d}$ for measurement of methane production, apparent total tract digestibility of fat, starch, and NDF, and energy and N balance. Two chambers were available and both treatments were tested in each of the replicates. The respiration calorimetry chambers were described in detail by Verstegen et al. (1987). Inside the chambers, temperature was maintained at $16^{\circ} \mathrm{C}$ and relative humidity at $70 \%$. Ventilation rate was $34.8 \mathrm{~m}^{3} / \mathrm{h}$ per cow and cows were exposed to $16 \mathrm{~h}$ of light per day. Water was freely available during the entire experiment. Cows were milked and fed twice daily at 0600 and $1700 \mathrm{~h}$. All data in this publication for experiment 1 pertain to the week the cows were in the respiration chambers. For methane production, apparent nutrient digestibility, and energy balance data, the experimental unit consists of the average data of 2 cows ( $n=5$ per treatment), whereas for production data (i.e., milk production, DMI) the experimental unit is the individual cow $(\mathrm{n}=10$ per treatment).

In experiment 2 , the same dietary treatments $(\mathrm{CON}$ vs. ADD) were compared in a crossover design with 2 periods of $28 \mathrm{~d}$, using 12 lactating Holstein-Friesian dairy cows with a milk production of $36.5 \pm 8.0 \mathrm{~kg} /$ day and $216 \pm 93$ DIM at the beginning of the experiment. The allocation of cows to dietary treatments was similar to that in experiment 1 . Cows were housed in tie-stalls. Animals were fed and milked twice daily
$(0600$ and $1700 \mathrm{~h})$. Water was freely available during the entire experiment.

\section{Animals and Housing}

The Animal Care and Use Committee of Wageningen University, the Netherlands approved the experimental protocol of experiment 1 . Cows were housed at the experimental facilities of Wageningen University, the Netherlands. For the first $14 \mathrm{~d}$ of each period cows were housed in tie-stalls and they were subsequently moved to respiration chambers for the last $7 \mathrm{~d}$ of each period.

The Animal Care and Use Committee of the Animal Sciences Group, Lelystad, the Netherlands, approved the experimental protocol of experiment 2 . Twelve lactating Holstein-Friesian dairy cows were included in the experiment. Ten of these cows were rumen fistulated. Cows were housed in tie-stalls at the experimental facilities of the Provimi Research and Innovation Centre, Velddriel, the Netherlands.

\section{Diets and Feeding}

Diet formulation (Table 1) was identical in both experiments. Diets were formulated to be isolipidic and isoenergetic on a theoretical net-energy basis (Van Es, 1975). The fat source in CON (fractionated palmitic acid; Hyprofat, Provimi B.V., Rotterdam, the Netherlands) was assumed to be rumen inert because of its high melting point and, thus, assumed not to have an effect on rumen fermentation other than dilution of rumen FOM (Dohme et al., 2000, 2001). The fat sources in the ADD treatment (lauric acid, myristic acid, and linseed oil) have been shown to decrease methane production in lactating cows (Dohme et al., 2001, 2004; Martin et al., 2008).

Diets were fed as TMR twice daily in equal portions before milking. For the first $10 \mathrm{~d}$ of the treatment period, diets were supplied ad libitum, after which feed intake was restricted to $95 \%$ of the DMI of the cow within a pair consuming the lowest amount of feed.

\section{Milk Production and Composition}

Milk yield was recorded daily in both experiments. In experiment 1, milk composition was calculated as the weighted average of the respective analyzed composition and milk yield of 4 milkings of d 19 and 20. For experiment 2 , the weighted averages of the respective analyzed composition and milk yield of 4 milkings of $d$ $27,28,55$, and 56 were used. Fat, protein, and lactose contents were determined according to ISO 9622 (ISO, 1999c), and MUN was determined using the $\mathrm{pH}$ difference technique (ISO 14637; ISO, 2004). Samples for 
Table 1. Feedstuff and chemical composition of TMR containing a rumen inert fat source (control, CON) or linseed oil, lauric acid, myristic acid, and Ca fumarate (ADD), used in experiments 1 and 2

\begin{tabular}{|c|c|c|}
\hline \multirow[b]{2}{*}{ Item } & \multicolumn{2}{|c|}{ Diet } \\
\hline & $\mathrm{CON}$ & $\mathrm{ADD}$ \\
\hline Grass silage, $\mathrm{g} / \mathrm{kg}$ of $\mathrm{DM}$ & 290 & 288 \\
\hline Maize silage, $\mathrm{g} / \mathrm{kg}$ of $\mathrm{DM}$ & 217 & 216 \\
\hline Barley straw, $\mathrm{g} / \mathrm{kg}$ of DM & 18 & 18 \\
\hline Concentrates, ${ }^{1} \mathrm{~g} / \mathrm{kg}$ of DM & 439 & 436 \\
\hline Fractionated palmitic acids $(\mathrm{C} 16: 0), \mathrm{g} / \mathrm{kg}$ of $\mathrm{DM}$ & 31 & \\
\hline Lauric acid (C12:0), $\mathrm{g} / \mathrm{kg}$ of DM & & 4 \\
\hline Myristic acid (C14:0), $\mathrm{g} / \mathrm{kg}$ of DM & & 12 \\
\hline Linseed oil, $\mathrm{g} / \mathrm{kg}$ of $\mathrm{DM}$ & & 15 \\
\hline Limestone, $\mathrm{g} / \mathrm{kg}$ of DM & 5 & \\
\hline Calcium fumarate, $\mathrm{g} / \mathrm{kg}$ of $\mathrm{DM}$ & & 7 \\
\hline Vitamin $\mathrm{E}, \mathrm{g} / \mathrm{kg}$ of DM & & 4 \\
\hline Gross energy (GE), MJ/kg of DM & 19.4 & 19.5 \\
\hline $\mathrm{DM}, \mathrm{g} / \mathrm{kg}$ & 588 & 580 \\
\hline Crude ash, $\mathrm{g} / \mathrm{kg}$ of DM & 79 & 78 \\
\hline $\mathrm{CP}, \mathrm{g} / \mathrm{kg}$ of $\mathrm{DM}$ & 170 & 170 \\
\hline $\mathrm{NDF}, \mathrm{g} / \mathrm{kg}$ of DM & 349 & 339 \\
\hline Crude fat, $\mathrm{g} / \mathrm{kg}$ of DM & 64 & 62 \\
\hline Starch, g/kg of DM & 168 & 165 \\
\hline Sugar, $\mathrm{g} / \mathrm{kg}$ of DM & 69 & 70 \\
\hline
\end{tabular}

${ }^{1}$ Concentrates were composed of $22.2 \%$ maize, $20.0 \%$ hominy feed, $15.0 \%$ dry beet pulp, $12.5 \%$ maize gluten feed, $10.9 \%$ barley, $10.0 \%$ formaldehyde-treated soybean meal, $6.2 \%$ soybean meal, $1.5 \%$ cane molasses, $1.0 \%$ mineral premix, $0.5 \% \mathrm{NaCl}$, and $0.2 \%$ limestone on a product basis.

analyses of milk fatty acid composition were collected on the same days, pooled, and analyzed according to the methods described by Vlaeminck et al. (2005) for experiment 1 and according to the methods of van Knegsel et al. (2007) for experiment 2.

\section{Sampling and Analyses Procedures}

Samples of TMR (approximately $500 \mathrm{~g}$ ) were obtained daily when fresh TMR was prepared. These samples were subsequently pooled per period and treatment and subsampled for analyses. Orts, when present, were collected and pooled per period and subsequently subsampled for analyses. Samples of TMR and orts were frozen $\left(-20^{\circ} \mathrm{C}\right)$ pending further analyses. Prior to analysis, samples were thawed and ground to pass a 1-mm screen.

During the measurement period in the respiration chambers, feces and urine were quantitatively collected, weighed, mixed thoroughly, and subsampled for analysis of gross energy (GE), DM, ash, N, crude fat, and NDF. Samples were frozen pending analyses, thawed, and ground to pass a 1-mm screen before analyses.

Gross energy was determined using bomb calorimetry (IKA-C700, Janke \& Kunkel, Heitersheim, Germany). Dry matter content was determined by drying at $103^{\circ} \mathrm{C}$ (ISO 6496; ISO 1999b) and ash content was determined by combustion at $550^{\circ} \mathrm{C}$ (ISO 5984; ISO 2002). The Kjeldahl method (ISO 5983; ISO 1997) was used to determine $\mathrm{N}$ content and $\mathrm{CP}$ was calculated by mul- tiplication of total $\mathrm{N}$ content by 6.25 . The crude fat content was analyzed using the Berntrop method (ISO 6492; ISO 1999a). Neutral detergent fiber was analyzed according to Van Soest et al. (1991), after pretreatment with amylase. The NDF contents reported include residual ash. Contents of ADF and acid detergent lignin were determined according to Van Soest (1973). The method of Ewers (ISO 6493: ISO, 2000) was used for determination of starch content and sugar content was determined by ethanol ( $40 \% \mathrm{vol} / \mathrm{vol})$ extraction and subsequent titrimetric determination of reducing sugars (as glucose) according to the Luff-Schoorl method (NEN 3571; NEN, 1974).

Because urine does not contain crude fat, NDF, or starch, contents of these components in the mixed samples of urine and feces were used for the determination of total tract apparent digestibility of crude fat, NDF, and starch.

\section{Evaluation of Rumen Fermentation Parameters}

Rumen fluid samples (200 $\mathrm{mL})$ in experiment 2 were collected $2 \mathrm{~h}$ post-feeding on d 27 and 28 of each period. Samples were obtained with a rigid polyvinyl chloride (PVC) tube, which was perforated at the end (2-mm holes) to allow the rumen fluid to enter the tube. A piece of plastic tubing was inserted into the PVC tube and by application of a vacuum, rumen fluid was aspirated from the rumen. After collection, sample containers were immersed in a bucket of ice water to 
stop microbial fermentation and samples were directly frozen after all samples had been taken.

\section{Manual Protozoa Counting}

Rumen fluid samples $(250 \mathrm{~mL})$ were obtained on d 5,21 , and 28 of each period in experiment 2, $30 \mathrm{~min}$ after feeding. Protozoa counts were performed manually according to the method described by Dehority (1993). Briefly, a sample of rumen fluid was strained through cheesecloth and a $10-\mathrm{mL}$ aliquot of strained rumen fluid was mixed with an equal volume of a $50 \%$ formalin solution in a graduated cylinder. Three replicate $1-\mathrm{mL}$ aliquots of the mixture were transferred to test tubes and 2 drops of brilliant green dye were added to each of the test tubes. The solution was well mixed and allowed to stand overnight. The next day, 9 $\mathrm{mL}$ of a $30 \%$ glycerol solution was added to each of the test tubes. The contents were well mixed and a $1-\mathrm{mL}$ sample was transferred to a Rafter Counting Chamber No.1 (Pyser-SGI Ltd., Edenbridge, UK). Protozoa were counted under a microscope (magnification $100 \times$ ), by counting $2 \times 20$ grids. This procedure was repeated with a second sample. When counts differed by no more than $10 \%$, the average of both counts was accepted. A deviation larger than $10 \%$ resulted in additional counting of both samples in a different counting chamber. The number of protozoa was then calculated from the overall average of the 4 counts.

\section{VFA and $\mathrm{NH}_{3}$ Analyses}

Analyses of VFA were performed according to the methods described by Van Nevel and Demeyer (1977). Rumen ammonia concentrations were determined according to the methods of Voigt and Steger (1967). Ammonia was flushed out with $\mathrm{K}_{2} \mathrm{CO}_{3}$ according to the microdiffusion method of Conway and O'Malley (1942) and subsequently captured in a boric acid solution and titrated with $0.01 \mathrm{M} \mathrm{HCl}$. The average of the 2 samples taken on subsequent days for each animal was used for further calculations.

\section{Statistical Analyses}

Data were analyzed using the MIXED procedure in Genstat (11th edition, Lawes Agricultural Trust, Rothamsted, UK). In experiment 1, all parameters related to energy balance were averaged over the 7-d measurement period, expressed per $\mathrm{kg}$ of $\mathrm{BW}^{0.75}$ per day, subjected to ANOVA, including dietary treatment $(\mathrm{CON}$ vs. ADD) as fixed, and experimental replicate $(\mathrm{i}=1, \ldots, 5)$ as random factor. In experiment 2 , all data were averaged over the last $7 \mathrm{~d}$ of each period and subjected to ANOVA, including dietary treatment as a fixed factor and cow and period as random factors. Protozoa counts were subjected to repeated measures ANOVA to take repeated samples within the same animal into account. Statistical significance was declared at $P<0.05$ and $P<0.10$ indicated a noteworthy trend.

\section{RESULTS}

\section{Feed Composition and Animal Performance}

The chemical composition of the TMR for both treatments is shown in Table 1 . As a result of restricted feeding, DMI was similar between treatments in both experiments (Table 2). Milk production tended to be lower for ADD in experiment 1, but milk production was unaffected by treatment in experiment 2. Milk fat content tended to be lower for ADD in experiment 1 and was decreased in experiment 2. Fat and protein corrected milk production for ADD was lower in experiment 1. Total daily milk fat yield was lower for the ADD groups in both experiments. Feeding ADD resulted in a lower MUN content (Expt. 1).

\section{Methane Production}

Methane production expressed in grams per day was $10 \%$ lower in experiment 1 for ADD $(P<0.05$, Table 3$)$. When expressed relative to gross energy intake (GEI), methane production was also lower for ADD compared with CON (5.7 and $6.2 \%$ of GEI, respectively). Due to a lower production of milk for ADD in Expt. 1, methane expressed per kilogram of milk was not different between treatments.

\section{Apparent Digestibility and Energy Balance}

Apparent digestibility of NDF and starch was unaffected by treatment (Table 4). Apparent fat digestibility was higher for ADD. No differences in GEI, metabolizable energy intake, or energy retention between treatments were found (Table 4). Cows on both treatments mobilized body reserves during the experimental period despite the fact that they were already in the advanced stages of lactation. The amount of energy lost as methane was lower for the ADD-fed cows. Cows receiving the ADD treatment partitioned less energy to milk production, which was reflected numerically in the overall energy balance.

\section{Rumen Fermentation Profile}

The total count of rumen protozoa tended to be lower for treatment ADD in experiment 2 (Table 5). 
Table 2. Milk production, milk composition, and DMI of dairy cows fed a control diet (CON) containing a rumen inert fat source or a diet containing a mixture of linseed oil, lauric acid, myristic acid, and Ca fumarate (ADD)

\begin{tabular}{|c|c|c|c|c|c|c|c|c|}
\hline \multirow[b]{2}{*}{ Item } & \multicolumn{4}{|c|}{ Experiment $1(\mathrm{n}=10$ per treatment $)$} & \multicolumn{4}{|c|}{ Experiment $2(\mathrm{n}=6$ per treatment) } \\
\hline & $\mathrm{CON}$ & $\mathrm{ADD}$ & SEM & $P$-value & $\mathrm{CON}$ & $\mathrm{ADD}$ & SEM & $P$-value \\
\hline Milk production, $\mathrm{kg} / \mathrm{d}$ & 28.9 & 26.1 & 0.86 & 0.053 & 32.0 & 33.2 & 0.59 & 0.175 \\
\hline FPCM,${ }^{1} \mathrm{~kg} / \mathrm{d}$ & 30.5 & 26.3 & 0.70 & 0.002 & 33.4 & 31.6 & 0.754 & 0.124 \\
\hline Milk fat content, $\%$ & 4.63 & 4.10 & 0.193 & 0.087 & 4.38 & 3.63 & 0.154 & 0.006 \\
\hline Milk protein content, \% & 3.27 & 3.35 & 0.079 & 0.533 & 3.54 & 3.47 & 0.075 & 0.539 \\
\hline $\mathrm{SCC}, \times 1,000$ cells $/ \mathrm{mL}$ & 123 & 208 & 77.7 & 0.458 & 136 & 169 & 20.3 & 0.271 \\
\hline Fat yield, $\mathrm{g} / \mathrm{d}$ & 1,313 & 1,079 & 38.7 & 0.002 & 1,374 & 1,176 & 48.8 & 0.017 \\
\hline Protein yield, g/d & 932 & 882 & 20.5 & 0.115 & 1,116 & 1,131 & 23.6 & 0.654 \\
\hline
\end{tabular}

${ }^{1}$ Fat- and protein-corrected milk.

This decrease was especially apparent on $\mathrm{d} 5$ of the experimental treatment, whereas the decrease was only numerical on d 21 and 28.

Concentrations of ruminal VFA were lower in cows on the ADD treatment. Within the VFA profile, the propionate proportion increased for the ADD treatment, whereas proportions of acetate and butyrate decreased, resulting in lower acetate-to-propionate ratio for the ADD treatment. Ammonia concentrations in the rumen fluid were lower for the ADD treatment.

\section{Milk Fatty Acid Composition}

The dietary treatments were clearly reflected in the milk fatty acid composition (Table 6). Concentrations of C12:0 and C14:0 in milk fat increased in both experiments as a result of the addition of these fatty acids to the ADD diet. The content of C16:0 in milk fat was higher for the CON treatment in both experiments, reflecting the addition of this fatty acid to the CON diet. The content of $\mathrm{C} 16: 1 \mathrm{c} 9$ was also higher in the $\mathrm{CON}$ diet in both experiments.

Clear shifts in odd and branched-chain fatty acids (OBCFA) were observed as a result of the dietary treatment. Contents in milk fat of $\mathrm{C} 15: 0$, iso $\mathrm{C} 15: 0$, and anteiso $\mathrm{C} 15: 0$ were all higher, and $\mathrm{C} 17: 0$ and $\mathrm{C} 17: 1$ cis-9 lower, with the ADD diet. Most shifts were consistent in both experiments. C18:1 cis-9 and C18:2 cis-9, 12 were higher with the CON diet, whereas $\mathrm{C} 18: 1$ trans-10+11 was higher with the ADD diet.

\section{DISCUSSION}

\section{Effects of the Additives on Enteric Methane Production}

The rationale behind the use of a mixture of feed additives was to make use of the known methanesuppressing properties of medium-chain fatty acids (MCFA) and linseed oil and to prevent accumulation of $\mathrm{H}$ by providing an alternative $\mathrm{H}$ sink in the form of Ca fumarate. The mixture of feed additives successfully lowered methane emissions from lactating dairy cows in this experiment.

Results of experiments investigating the methanemitigating effect of dietary fumarate are equivocal, but in situations of an increased concentration of $\mathrm{H}$ in the rumen, fumarate may be an effective $\mathrm{H}$ sink (Ungerfeld et al., 2007). In 2 experiments, in which fumarate or fumaric acid was fed to ruminants, decreases in methane production were observed (Bayaru et al., 2001; Wallace et al., 2006). However, other groups reported

Table 3. Methane $\left(\mathrm{CH}_{4}\right)$ production from dairy cows fed a control diet $(\mathrm{CON})$ containing a rumen inert fat source or a diet containing a mixture of linseed oil, lauric acid, myristic acid, and Ca fumarate (ADD), $\mathrm{n}=5$ per treatment

\begin{tabular}{|c|c|c|c|c|}
\hline \multirow[b]{2}{*}{ Item } & \multicolumn{2}{|c|}{ Diet } & \multirow[b]{2}{*}{ SEM } & \multirow[b]{2}{*}{$P$-value } \\
\hline & $\mathrm{CON}$ & $\mathrm{ADD}$ & & \\
\hline $\mathrm{CH}_{4}, \mathrm{~g} / \mathrm{d}$ & 362 & 325 & 7.1 & 0.021 \\
\hline $\mathrm{CH}_{4}, \mathrm{~g} / \mathrm{kg}$ of $\mathrm{DMI}$ & 22.1 & 20.5 & 0.65 & 0.146 \\
\hline $\mathrm{CH}_{4}, \%$ of $\mathrm{GEI}^{1}$ & 6.2 & 5.7 & 0.10 & 0.025 \\
\hline $\mathrm{CH}_{4}, \mathrm{~g} / \mathrm{kg}$ of milk & 12.8 & 12.7 & 0.43 & 0.906 \\
\hline
\end{tabular}

${ }^{1}$ Gross energy intake. 
Table 4. Energy balance and total tract apparent nutrient digestibility in dairy cows fed a control diet (CON) containing a rumen inert fat source or a diet containing a mixture of linseed oil, lauric acid, myristic acid, and Ca fumarate (ADD), $\mathrm{n}=5$ per treatment

\begin{tabular}{|c|c|c|c|c|}
\hline Item & $\mathrm{CON}$ & $\mathrm{ADD}$ & SEM & $P$-value \\
\hline Gross energy intake, $\mathrm{kJ} / \mathrm{kg}$ of $\mathrm{BW}^{0.75}$ per $\mathrm{d}$ & 2,852 & 2,757 & 61.5 & 0.339 \\
\hline ME intake, ${ }^{1} \mathrm{~kJ} / \mathrm{kg}$ of $\mathrm{BW}^{0.75}$ per d & 1,759 & 1,737 & 59.0 & 0.800 \\
\hline ME:GE ratio, ${ }^{2} \%$ & 61.8 & 62.9 & 0.94 & 0.566 \\
\hline Methane production, $\mathrm{kJ} / \mathrm{kg}$ of $\mathrm{BW}^{0.75}$ per $\mathrm{d}$ & 177.1 & 157.3 & 3.46 & 0.015 \\
\hline Energy retention total, ${ }^{3} \mathrm{~kJ} / \mathrm{kg}$ of $\mathrm{BW}^{0.75}$ per d & -167 & -65 & 45.9 & 0.189 \\
\hline Energy retention protein, ${ }^{4} \mathrm{~kJ} / \mathrm{kg}$ of $\mathrm{BW}^{0.75}$ per $\mathrm{d}$ & 8.7 & 28.6 & 8.62 & 0.178 \\
\hline Energy retention fat, ${ }^{5} \mathrm{~kJ} / \mathrm{kg}$ of $\mathrm{BW}^{0.75}$ per $\mathrm{d}$ & -176 & -93 & 41.1 & 0.228 \\
\hline NDF digestibility, $\%$ & 69.6 & 68.1 & 0.68 & 0.173 \\
\hline Starch digestibility, \% & 97.5 & 97.8 & 0.15 & 0.194 \\
\hline Fat digestibility, \% & 58.1 & 69.4 & 1.20 & 0.003 \\
\hline
\end{tabular}

${ }^{1} \mathrm{ME}$ intake $=$ gross energy intake $(\mathrm{GEI})-$ methane production - energy in feces + urine.

${ }^{2} \mathrm{GE}=$ gross energy.

${ }^{3}$ Energy retention total $=$ MEI - heat production - energy in milk.

${ }^{4}$ Energy retention protein $=$ protein gain $\times 23.6 \mathrm{~kJ} / \mathrm{g}$.

${ }^{5}$ Energy retention fat $=$ energy retention total - energy retention protein.

no effects on methane emission when fumarate was fed (Beauchemin and McGinn, 2006; Kolver and Aspin, 2006; Molano et al., 2008). In the current experiment, $116 \mathrm{~g}$ of Ca fumarate was fed per animal per day. If all Ca fumarate fed to the animal would have been converted to propionate in the rumen, methane production would have decreased by $4.9 \mathrm{~g}$ of methane and the maximum theoretical decrease in methane production thus attributable to the addition of $\mathrm{Ca}$ fumarate in these diets could only account for little over $1 \%$ of total methane emissions. For this experiment, we can probably assume that effects of $\mathrm{Ca}$ fumarate addition were negligible and the decrease in methane emitted can be ascribed to the fatty acids and oils used.
Addition of dietary fats and oils, the main components of the mixture, has been shown to lower methane emissions from ruminants in numerous studies (Machmüller et al., 2003; Jordan et al., 2006b; Martin et al., 2008). Martin et al. (2008) demonstrated a $64 \%$ decrease in daily methane production, determined with the $\mathrm{SF}_{6^{-}}$ technique, when linseed oil (5.8\% of diet DM) was dosed orally to lactating dairy cows twice daily. This decrease was hypothesized to result from a decrease in total tract NDF digestibility $(-11 \%)$. Although DMI decreased $(-26 \%)$, methane production per kilogram of OM intake decreased as well $(-52 \%)$. Martin et al. (2008) hypothesized that, in their experiment, NDF digestibility was considerably depressed in the rumen and

Table 5. Volatile fatty acid, ammonia concentrations, and protozoa numbers in rumen fluid taken $2 \mathrm{~h}$ after feeding of fistulated dairy cows fed a control diet $(\mathrm{CON})$ containing a rumen inert fat source or a diet containing a mixture of linseed oil, lauric acid, myristic acid, and Ca fumarate (ADD), $\mathrm{n}=5$ per treatment

\begin{tabular}{|c|c|c|c|c|}
\hline \multirow[b]{2}{*}{ Item } & \multicolumn{2}{|c|}{ Diet } & \multirow[b]{2}{*}{ SEM } & \multirow[b]{2}{*}{$P$-value } \\
\hline & $\mathrm{CON}$ & $\mathrm{ADD}$ & & \\
\hline VFA concentration, mmol/L & 134.9 & 126.3 & 2.28 & 0.029 \\
\hline Acetate, $\%$ of VFA & 60.3 & 58.6 & 0.32 & 0.006 \\
\hline Propionate, $\%$ of VFA & 19.8 & 23.0 & 0.40 & $<0.001$ \\
\hline Butyrate, $\%$ of VFA & 15.3 & 13.6 & 0.39 & 0.015 \\
\hline Isobutyrate, $\%$ of VFA & 1.1 & 1.0 & 0.05 & 0.108 \\
\hline Valerate, $\%$ of VFA & 1.6 & 1.8 & 0.09 & 0.205 \\
\hline Isovalerate, $\%$ of VFA & 1.9 & 2.0 & 0.08 & 0.210 \\
\hline Acetate:propionate ratio & 3.1 & 2.6 & 0.06 & $<0.001$ \\
\hline $\mathrm{NH}_{3}, \mathrm{mg} / 100 \mathrm{~mL}$ & 36.6 & 30.7 & 1.16 & 0.007 \\
\hline Protozoa count d $5, \times 10^{5} / \mathrm{mL}$ & 2.60 & 1.73 & 0.191 & 0.012 \\
\hline Protozoa count d $21, \times 10^{5} / \mathrm{mL}$ & 2.64 & 1.75 & 0.343 & 0.105 \\
\hline Protozoa count d $28, \times 10^{5} / \mathrm{mL}$ & 2.66 & 2.25 & 0.177 & 0.139 \\
\hline Protozoa count average, ${ }^{1} \times 10^{5} / \mathrm{mL}$ & 2.63 & 1.91 & 0.121 & 0.088 \\
\hline
\end{tabular}

${ }^{1} P$-value of repeated measures analysis, time effect $P=0.498$; time $\times$ treatment $P=0.586$. 
Table 6. Milk fatty acid composition of milk from dairy cows fed a control diet (CON) containing a rumen inert fat source or a diet containing a mixture of linseed oil, lauric acid, myristic acid and Ca-fumarate (ADD)

\begin{tabular}{|c|c|c|c|c|c|c|c|c|}
\hline C6:0 & 1.85 & 1.65 & 0.073 & 0.079 & 1.80 & 1.68 & 0.095 & 0.390 \\
\hline C8:0 & 1.06 & 0.95 & 0.045 & 0.130 & 0.88 & 0.85 & 0.050 & 0.693 \\
\hline C10:0 & 2.30 & 2.11 & 0.098 & 0.206 & 1.78 & 1.77 & 0.103 & 0.950 \\
\hline C12:0 & 2.58 & 3.73 & 0.083 & $<0.001$ & 2.10 & 3.14 & 0.069 & $<0.001$ \\
\hline C16:0 & 35.3 & 22.6 & 0.478 & $<0.001$ & 36.5 & 23.5 & 0.345 & $<0.001$ \\
\hline C16:1 cis-9 & 2.03 & 1.41 & 0.122 & 0.006 & 2.30 & 1.61 & 0.053 & $<0.001$ \\
\hline C15:0 & 0.79 & 0.92 & 0.035 & 0.028 & 0.78 & 0.90 & 0.024 & 0.004 \\
\hline $\mathrm{C} 15: 0$ iso & 0.17 & 0.20 & 0.005 & 0.003 & 0.14 & 0.17 & 0.004 & 0.002 \\
\hline $\mathrm{C} 15: 0$ anteiso & 0.37 & 0.47 & 0.021 & 0.009 & 0.36 & 0.42 & 0.007 & $<0.001$ \\
\hline C17:0 & 0.49 & 0.42 & 0.014 & 0.009 & 0.39 & 0.35 & 0.011 & 0.038 \\
\hline $\mathrm{C} 17: 0$ iso & 0.31 & 0.34 & 0.014 & 0.127 & 0.19 & 0.20 & 0.007 & 0.639 \\
\hline $\mathrm{C} 18: 2$ cis $-9,12$ & 1.63 & 1.39 & 0.043 & 0.003 & 1.65 & 1.38 & 0.052 & 0.004 \\
\hline $\mathrm{C} 18: 3$ cis- $9,12,15$ & 0.39 & 0.47 & 0.034 & 0.143 & 0.47 & 0.51 & 0.015 & 0.068 \\
\hline C20:0 & 0.09 & 0.13 & 0.017 & 0.107 & 0.12 & 0.11 & 0.002 & 0.001 \\
\hline C20:1 cis-9 & 0.19 & 0.34 & 0.045 & 0.044 & 0.12 & 0.11 & 0.006 & 0.152 \\
\hline
\end{tabular}

that this was partly compensated for by fermentation in the hindgut. Because the rumen is the main site of methanogenesis, this could explain the major decrease in methane production. In the present study, linseed oil was fed at a much lower level (1.5\% of DM) and was mixed in the TMR, resulting in a much more gradual intake along the day. Total-tract NDF digestibility was not affected in the present experiment, but it is possible that ruminal NDF fermentation was decreased in cows fed the ADD diet and that this was completely compensated for by increased NDF fermentation in the large intestine. Beauchemin et al. (2009) added 9.3\% crushed linseed to the diet of lactating dairy cows and observed an $18 \%$ decrease in methane production in climate chambers without effects on DMI. However, when methane production was expressed per kilogram of digestible DM, no differences in methane production were observed. The decreased methane production reported by Beauchemin et al. (2009), thus, appears to be completely attributable to a decreased DM digestibility. In the study of Beauchemin et al. (2009) the number of rumen protozoa was suppressed when cows were fed crushed linseed. In the present experiment, the number of rumen protozoa also tended to be lower for ADD, which may explain the decreased methane production observed. Defaunation has been associated with lower methanogenesis due to the symbiotic relationship between methanogens and protozoa (Hegarty, 1999).
Odongo et al. (2007) observed a 36\% decrease in daily methane production when myristic acid was added to the diets of lactating dairy cows at $5 \%$ of diet DM. Dry matter intake tended to be lower for the myristic acid-supplemented cows. Dohme et al. (2004) fed diets containing either $\mathrm{C} 12: 0, \mathrm{C} 14: 0$, or $\mathrm{C} 18: 0$ to dairy cows (5\% of DM). Methane production was not affected by the inclusion of C14:0, but was decreased by $21 \%$ for the $\mathrm{C} 12: 0$ diet compared with the C18:0 diet. However, the inclusion of C12:0 also suppressed DMI and when methane production was expressed per kilogram of DMI, it was no longer different from the control. Jordan et al. (2006a) fed increasing quantities of coconut oil $(125,250$, and $375 \mathrm{~g} / \mathrm{d} ; 1.3,2.7$, and $4.6 \%$ of DM, consisting predominantly of $\mathrm{C} 12: 0$ and $\mathrm{C} 14: 0)$ to beef heifers. Daily methane emissions were decreased (13, 20 , and $39 \%$, respectively), but DMI also linearly decreased with increasing concentrations of coconut oil in the diet. Dry matter digestibility also decreased linearly with increasing dose of coconut oil, probably reflecting a dose-dependent decrease in NDF digestibility. In another experiment by Jordan et al. (2006b), $250 \mathrm{~g}$ of refined coconut oil (equivalent to $2.7 \%$ of DM) was fed to beef heifers on a daily basis. Methane production was decreased by $19 \%$, but digestibility coefficients were not affected. However, total ruminal VFA concentrations were suppressed and the total number of protozoa was decreased by $63 \%$. 
The $10 \%$ decrease in methane production achieved in our study appears rather modest when compared with that in other studies (Jordan et al., 2006b; Odongo et al., 2007; Martin et al., 2008; Beauchemin et al., 2009). However, the methane decreases achieved in the other studies were, at least in part, related to decreases in DMI (Beauchemin et al., 2009), a difference in fat content between the control ration and the treatment ration (Jordan et al., 2006b), or both (Jordan et al., 2006a; Martin et al., 2008). Dry matter intake is one of the main drivers of the quantity of methane produced (Ellis et al., 2009) and differences in DMI between treatments as a consequence of the added oil and fat will cause an indirect effect on methane production. Differences in fat content between the control ration and the treatment ration will inherently lead to differences in dietary FOM content and this in itself will also lead to differences in the quantity of methane produced. In this experiment, we excluded differences in DMI and in dietary fat content as factors indirectly influencing methane emissions.

Because DMI and dietary fat content did not differ, results of the present experiment show that the addition of the products used in this experiment have an effect on methane emissions related to causal factors other than indirect effects on DMI and differences in dietary fat content. This additional effect might be related to specific effects of the fats and oils on the rumen microbial consortium (Dohme et al., 2001; Zhang et al., 2008).

\section{Possible Mode of Action of Methane Decrease}

The ruminal concentration of VFA was suppressed for the ADD treatment, which may indicate a lower level of rumen fermentation or increased absorption of VFA from the rumen. The overall decrease in rumen fermentation may provide a partial explanation for the observed lower methane production. Dietary fat addition is known to lower rumen degradation of carbohydrates, specifically structural carbohydrates. This negative effect is more pronounced when linseed oil is added to the diet compared with saturated fats (Doreau and Chilliard, 1997).

Within the VFA, the proportion of propionate increased, possibly reflecting decreased structural carbohydrate degradation. Indeed, the fatty acids and linseed oil used in this study have been shown to decrease structural carbohydrate degradation in other studies (Jordan et al., 2006a; Martin et al., 2008). A shift toward propionate-orientated fermentation is commonly observed when feeding oils to dairy cows (McGinn et al., 2004; Beauchemin and McGinn, 2006). This increased propiogenesis may also result from an increased $\mathrm{H}$ pressure in the rumen as a consequence of the decreased methanogenesis. Total tract apparent digestibility of NDF was not affected by treatment, and decreased structural carbohydrate degradation, thus, does not appear to offer an explanation for the observed decrease in methane emission. It could, however, be possible that rumen fermentation of the NDF fraction was negatively affected by the inclusion of fats and oils in the ADD diet, but that this was compensated for by fermentation in the large intestine. The compensatory fermentation in the hindgut would yield fewer nutrients for the dairy cow and could possibly explain the lower milk production observed on the ADD treatment. The fermentation of NDF in the large intestine could also yield less methane per unit of NDF fermented (Immig, 1996), due to the possibility of reductive acetogenesis in the hindgut.

Protozoa numbers tended to be lower in the ADD treatment. Defaunation has been associated with lower methanogenesis due to the symbiotic relationship between methanogens and protozoa (Hegarty, 1999). Defaunated animals often have a higher ruminal propionate concentration (Bird et al., 2008) and lower rumen $\mathrm{NH}_{3}$ levels in rumen fluid (Eugène et al., 2004), which was also observed in this experiment. Thus, the inhibitory effect of the fats and oils added on the rumen protozoa may be another explanation for the observed methane decrease. Partial defaunation has been observed before when feeding MCFA (Lovett et al., 2003; Hristov et al., 2004) or linseed oil (Broudiscou et al., 1994; Zhang et al., 2008) to ruminants.

\section{Changes in Milk Composition}

Milk fat content was lower for the ADD group. A decrease in milk fat content has been observed before when feeding linseed oil to dairy cows (e.g., Martin et al., 2008), and results from the accumulation of products of incomplete ruminal biohydrogenation of the unsaturated fatty acids in linseed oil (Bauman and Griinari, 2003). The lower milk fat content on this treatment can be explained by the inhibition of mammary lipogenesis by these intermediates. Milk urea nitrogen was lower for the ADD treatment, possibly reflecting a decreased formation of rumen ammonia as a result of defaunation (Eugène et al., 2004). In experiment 2, ruminal ammonia concentrations and protozoal numbers were in fact lower for the ADD treatment.

Vlaeminck and Fievez (2005) developed equations to predict the quantity of methane produced by dairy cows from the proportion of odd and branched-chain fatty acids in milk. They predicted that iso C15:0 was positively, and C15:0 negatively related to methanogenesis. Our data however, indicate C15:0 and iso C15:0 
to be negatively associated with methane production. In recent work by Chilliard et al. (2009), C15:0 was positively correlated with methane production. The concentration of iso C15:0 was not found to be related to methanogenesis in that experiment. Vlaeminck and Fievez (2005) explained the relationship they observed by a higher enrichment of iso C15:0 in H-producing bacteria, whereas propionate-producing bacteria contained a relatively high proportion of C15:0. In experiment 2, C15:0 concentrations increased by approximately $15 \%$, suggesting an increase in propionate-producing bacteria. This was also confirmed by the higher proportion of propionate in rumen fluid. However, iso C15:0 concentrations in milk also increased by 18 to $21 \%$ when the ADD ration was fed. This suggests an increase in H-producing bacteria. The equation predicted almost equal methane production in both treatments in this experiment, whereas in reality, a $10 \%$ decrease was observed. However, Vlaeminck and Fievez (2005) expressed methane proportionally to the VFA concentration $\left(\mathrm{CH}_{4} / \mathrm{VFA}\right)$; in this experiment, methane production was $10 \%$ lower for the ADD treatment, but VFA production was also $6 \%$ lower for this treatment. Expressing methane production proportionally to VFA in this experiment would lead to similar values for both treatments.

\section{CONCLUSIONS}

The diet containing a mixture of C12:0, C14:0, linseed oil, and Ca fumarate successfully lowered daily methane emissions from dairy cows, when compared with an isolipidic control diet fed at similar DMI. However, methane emissions per kilogram of FPCM were not affected by feeding the mixture. Earlier reported methane decreases for these fats and oils appear to be largely caused by indirect methane decreases as a consequence of lower DMI and different fat contents between diets.

\section{REFERENCES}

Bauman, D. E., and J. M. Griinari. 2003. Nutritional regulation of milk fat synthesis. Annu. Rev. Nutr. 23:203-227.

Bayaru, E., S. Kanda, T. Kamada, H. Itabashi, S. Andoh, T. Nishida, M. Ishida, T. Itoh, K. Nagara, and Y. Isobe. 2001. Effect of fumaric acid on methane production, rumen fermentation and digestibility of cattle fed roughage alone. Anim. Sci. J. 72:139-146.

Beauchemin, K. A., and S. M. McGinn. 2006. Methane emissions from beef cattle: Effects of fumaric acid, essential oil, and canola oil. J. Anim. Sci. 84:1489-1496.

Beauchemin, K. A., S. M. McGinn, C. Benchaar, and L. Holtshausen. 2009. Crushed sunflower, flax, or canola seeds in lactating dairy cow diets: Effects on methane production, rumen fermentation, and milk production. J. Dairy Sci. 92:2118-2127.

Bird, S. H., R. S. Hegarty, and R. Woodgate. 2008. Persistence of defaunation effects on digestion and methane production in ewes. Aust. J. Exp. Agric. 48:152-155.
Broudiscou, L., S. Pochet, and C. Poncet. 1994. Effect of linseed oil supplementation on feed degradation and microbial synthesis in the rumen of ciliate-free and refaunated sheep. Anim. Feed Sci. Technol. 49:189-202.

Chilliard, Y., C. Martin, J. Rouel, and M. Doreau. 2009. Milk fatty acids in dairy cows fed whole crude linseed, extruded linseed, or linseed oil, and their relationship with methane output. J. Dairy Sci. 92:5199-5211.

Conway, E. J., and E. O'Malley. 1942. Microdiffusion methods. Ammonia and urea using buffered absorbents (revised methods for ranges greater than 10mug. N). Biochem. J. 36:655-661.

Dehority, B. A. 1993. Laboratory Manual for Classification and Morphology of Rumen Ciliate Protozoa. Page 120. CRC Press, Boca Raton, FL.

Dohme, F., A. Machmüller, F. Sutter, and M. Kreuzer. 2004. Digestive and metabolic utilization of lauric, myristic and stearic acid in cows, and associated effects on milk fat quality. Arch. Anim. Nutr. 58:99-116.

Dohme, F., A. Machmüller, A. Wasserfallen, and M. Kreuzer. 2000. Comparative efficiency of various fats rich in medium-chain fatty acids to suppress ruminal methanogenesis as measured with RUSITEC. Can. J. Anim. Sci. 80:473-482.

Dohme, F., A. Machmüller, A. Wasserfallen, and M. Kreuzer. 2001. Ruminal methanogenesis as influenced by individual fatty acids supplemented to complete ruminant diets. Lett. Appl. Microbiol. $32: 47-51$.

Doreau, M., and Y. Chilliard. 1997. Digestion and metabolism of dietary fat in farm animals. Br. J. Nutr. 78:S15-S35.

Ellis, J. L., J. Dijkstra, E. Kebreab, A. Bannink, N. E. Odongo, B. W. McBride, and J. France. 2008. Aspects of rumen microbiology central to mechanistic modelling of methane production in cattle. J. Agric. Sci. 146:213-233.

Ellis, J. L., E. Kebreab, N. E. Odongo, K. Beauchemin, S. McGinn, J. D. Nkrumah, S. S. Moore, R. Christopherson, G. K. Murdoch, B. W. McBride, E. K. Okine, and J. France. 2009. Modeling methane production from beef cattle using linear and nonlinear approaches. J. Anim. Sci. 87:1334-1345.

Eugène, M., H. Archimède, and D. Sauvant. 2004. Quantitative metaanalysis on the effects of defaunation of the rumen on growth, intake and digestion in ruminants. Livest. Prod. Sci. 85:81-97.

Eugene, M., D. Masse, J. Chiquette, and C. Benchaar. 2008. Short communication: Meta-analysis on the effects of lipid supplementation on methane production in lactating dairy cows. Can. J. Anim. Sci. 88:331-334.

Forster, P., V. Ramaswamy, P. Artaxo, T. Berntsen, R. Betts, D. W. Fahey, J. Haywood, J. Lean, D. C. Lowe. G. Myhre, J. Nganga, R. Prinn, G. Raga, M. Schulz, and R. Van Dorland. 2007. Changes in atmospheric constituents and in radiative forcing. In Climate Change 2007: The Physical Science Basis. Contribution of Working Group I to the Fourth Assessment Report of the Intergovernmental Panel on Climate Change. S. Solomon, D. Qin, M. Manning, Z. Chen, M. Marquis, K. B. Averyt, M. Tignor, and H. L. Miller, ed. Cambridge University Press, Cambridge, UK.

Hegarty, R. S. 1999. Reducing rumen methane emissions through elimination of rumen protozoa. Aust. J. Agric. Res. 50:1321-1327.

Hristov, A. N., K. L. Grandeen, J. K. Ropp, and M. A. McGuire. 2004. Effect of sodium laurate on ruminal fermentation and utilization of ruminal ammonia nitrogen for milk protein synthesis in dairy cows. J. Dairy Sci. 87:1820-1831.

Immig, I. 1996. The rumen and hindgut as source of ruminant methanogenesis. Environ. Monit. Assess. 42:57-72.

ISO. 1997. Animal feeding stuffs-Determination of nitrogen content and calculation of crude protein content-Kjeldahl method. Iso 5983:1997. International Organization for Standardization, Geneva, Switzerland.

ISO. 1999a. Animal feeding stuffs - Determination of fat content. International Organization for Standardization, Geneva, Switzerland.

ISO. 1999b. Animal feeding stuffs-Determination of moisture and other volatile matter content. International Organization for Standardization, Geneva, Switzerland. 
ISO. 1999c. Whole milk. Determination of milk fat, protein and lactose content-Guidance on the operation of mid-infrared instruments. International Organization for Standardization, Geneva, Switzerland.

ISO. 2000. Animal feeding stuffs-Determination of starch contentPolarimetric method. International Organization for Standardization, Geneva, Switzerland.

ISO. 2002. Animal feeding stuffs-Determination of crude ash. International Organization for Standardization, Geneva, Switzerland.

ISO. 2004. Milk-Determination of urea content-Enzymatic method using difference in $\mathrm{pH}$ (reference method). International Organization for Standardization, Geneva, Switzerland.

Johnson, K. A., and D. E. Johnson. 1995. Methane emissions from cattle. J. Anim. Sci. 73:2483-2492.

Jordan, E., D. K. Lovett, M. Hawkins, J. J. Callan, and F. P. O'Mara 2006a. The effect of varying levels of coconut oil on intake, digestibility and methane output from continental cross beef heifers. Anim. Sci. 82:859-865.

Jordan, E., D. K. Lovett, F. J. Monahan, J. Callan, B. Flynn, and F. P. O'Mara. 2006b. Effect of refined coconut oil or copra meal on methane output and on intake and performance of beef heifers. J. Anim. Sci. 84:162-170.

Kolver, A. S., and P. W. Aspin. 2006. Supplemental fumarate did not influence milksolids or methane production from dairy cows fed high quality pasture. Proc. N.Z. Soc. Anim. Prod. 66:409-415.

Lovett, D., S. Lovell, L. Stack, J. Callan, M. Finlay, J. Conolly, and F. P. O'Mara. 2003. Effect of forage/concentrate ratio and dietary coconut oil level on methane output and performance of finishing beef heifers. Livest. Prod. Sci. 84:135-146.

Machmüller, A. 2006. Medium-chain fatty acids and their potential to reduce methanogenesis in domestic ruminants. Agric. Ecosyst. Environ. 112:107-114.

Machmüller, A., C. R. Soliva, and M. Kreuzer. 2003. Methane-suppressing effect of myristic acid in sheep as affected by dietary calcium and forage proportion. Br. J. Nutr. 90:529-540.

Martin, C., J. Rouel, J. P. Jouany, M. Doreau, and Y. Chilliard. 2008 Methane output and diet digestibility in response to feeding dairy cows crude linseed, extruded linseed, or linseed oil. J. Anim. Sci. $86: 2642-2650$

McGinn, S. M., K. A. Beauchemin, T. Coates, and D. Colombatto. 2004. Methane emissions from beef cattle: Effects of monensin sunflower oil, enzymes, yeast, and fumaric acid. J. Anim. Sci. 82:3346-3356.

Molano, G., T. W. Knight, and H. Clark. 2008. Fumaric acid supplements have no effect on methane emissions per unit of feed intake in wether lambs. Aust. J. Exp. Agric. 48:165-168.

Nederlandse Norm (NEN). 1974. Onderzoekingsmethoden voor veevoeders-Bepaling van het gehalte aan reducerende suiker, ruwe totaal suiker, saccharose en ruwe lactose. NEN (Nederlandse Norm), Delft, the Netherlands.
Odongo, N. E., M. M. Or-Rashid, E. Kebreab, J. France, and B. W McBride. 2007. Effect of supplementing myristic acid in dairy cow rations on ruminal methanogenesis and fatty acid profile in milk. J. Dairy Sci. 90:1851-1858.

Steinfeld, H., P. Gerber, T. Wassenaar, V. Castel, M. Rosales, and C. de Haan. 2006. Livestock's long shadow: Environmental issues and options. Food and Agriculture Organization of the United Nations, Rome, Italy.

Ungerfeld, E. M., R. A. Kohn, R. J. Wallace, and C. J. Newbold. 2007. A meta-analysis of fumarate effects on methane production in ruminal batch cultures. J. Anim. Sci. 85:2556-2563.

Van Es, A. J. H. 1975. Feed evaluation for dairy cows. Livest. Prod. Sci. 2:95-107.

van Knegsel, A. T. M., H. van den Brand, J. Dijkstra, W. M. van Straalen, M. J. W. Heetkamp, S. Tamminga, and B. Kemp. 2007. Dietary energy source in dairy cows in early lactation: Energy partitioning and milk composition. J. Dairy Sci. 90:1467-1476.

Van Nevel, C. J., and D. I. Demeyer. 1977. Effect of monensin on rumen metabolism in vitro. Appl. Environ. Microbiol. 34:251-257.

Van Soest, P. J. 1973. Collaborative study of acid-detergent fiber and lignin. J. Assoc. Off. Anal. Chem. 56:781-784.

Van Soest, P. J., J. B. Robertson, and B. A. Lewis. 1991. Methods for dietary fiber, neutral detergent fiber, and nonstarch polysaccharides in relation to animal nutrition. J. Dairy Sci. 74:3583-3597.

Verstegen, M. W. A., W. Van der Hel, H. A. Brandsma, A. M. Henken, and A. M. Bransen. 1987. The Wageningen respiration unit for animal production research: A description of the equipment and its possibilities. Pages 21-48 in Energy Metabolism in Farm Animals: Effects of Housing. Stress and Disease. M. W. A. Verstegen and A. M. Henken, ed. Martinus Nijhoff Publishers, Dordrecht, the Netherlands.

Vlaeminck, B., C. Dufour, A. M. van Vuuren, A. R. J. Cabrita, R J. Dewhurst, D. Demeyer, and V. Fievez. 2005. Use of odd and branched-chain fatty acids in rumen contents and milk as a potential microbial marker. J. Dairy Sci. 88:1031-1042.

Vlaeminck, B., and V. Fievez. 2005. Milk odd and branched chain fatty acids to predict ruminal methanogenesis in dairy cows. Comm. Appl. Biol. Sci. 70:43-47.

Voigt, J., and H. Steger. 1967. About the determination of ammonia, urea, and ketone bodies in biological material using a modified type of micro diffusion vessel. Arch. Anim. Nutr. 17:289-293.

Wallace, R. J., T. A. Wood, A. Rowe, J. Price, D. R. Yanez, S. P. Williams, and C. J. Newbold. 2006. Encapsulated fumaric acid as a means of decreasing ruminal methane emissions. Int. Congr. Ser. 1293:148-151.

Zhang, C. M., Y. Q. Guo, Z. P. Yuan, Y. M. Wu, J. K. Wang, J. X. Liu, and W. Y. Zhu. 2008. Effect of octadeca carbon fatty acids on microbial fermentation, methanogenesis and microbial flora in vitro. Anim. Feed Sci. Technol. 146:259-269. 